\title{
Altered Levels of Basal Cortisol in Healthy Subjects with a I I8G Allele in Exon I of the Mu Opioid Receptor Gene
}

\author{
Gavin Bart', K Steven LaForge', Lisa Borg', Charles Lilly', Ann Ho' and Mary Jeanne Kreek*,' \\ 'The Laboratory of the Biology of Addictive Diseases, The Rockefeller University, New York, NY, USA
}

\begin{abstract}
The mu opioid receptor is centrally involved in the development of the addictive diseases. It also modulates the stress responsive hypothalamic-pituitary-adrenal axis. Receptors encoded by the variant II8G polymorphism in exon I of the mu opioid receptor gene have a threefold increase in beta-endorphin binding and beta-endorphin is three times more potent in receptor-mediated activation of $G$ protein-coupled inwardly rectifying potassium channels. Humans with this variant have increased stress response following opioid antagonism. Here, we study basal levels of adrenocorticotropic hormone and cortisol in subjects with this variant. In all, 59 healthy adults were genotyped and had morning levels of adrenocorticotropic hormone and cortisol measured following intravenous administration of saline placebo. Subjects with a I I8G allele had significantly greater levels of cortisol than subjects with the prototype gene. Groups did not differ in levels of adrenocorticotropic hormone. A planned comparison revealed significantly greater cortisol in females with at least one copy of the 118G allele compared to females with the prototype gene. There was no significant effect of gender alone, nor was there a significant interaction between gender and genotype, on ACTH or cortisol. Subjects with at least one copy of the II8G allele have increased basal levels of cortisol, which may influence the susceptibility to and treatment of the stress responsive dyscrasia. Neuropsychopharmacology (2006) 31, 2313-2317. doi: I0.1038/s.npp. I 301 I28; published online 21 June 2006
\end{abstract}

Keywords: cortisol; adrenocorticotropin; hypothalamic-pituitary-adrenal axis; opioid receptor; genetics; human

\section{INTRODUCTION}

The addictive diseases and several other psychiatric disorders are characterized by alterations in the stress responsive hypothalamic-pituitary-adrenal (HPA) axis (Ehlert et al, 2001; Kreek and Koob, 1998). In the case of the addictive diseases, these alterations are primarily due to the pharmacological effects of drugs of abuse but are also influenced by developmental, environmental, and genetic factors. As an example of the latter, nonalcoholic sons of alcoholic fathers have altered HPA responsiveness to alcohol and mu opioid receptor antagonism compared to sons of nonalcoholic fathers (King et al, 1998; Schuckit et al, 1987; Wand et al, 1998). In fact, up to $50 \%$ of interindividual differences in basal and stress-induced cortisol levels in healthy human volunteers may be explained by genetic factors (Federenko et al, 2004; Linkowski et al, 1993). While this is likely due to the interaction of several genes, so too are the genetic determinants of drug addiction. Indeed, several genes have been associated with the

\footnotetext{
*Correspondence: Dr MJ Kreek, The Laboratory of the Biology of Addictive Diseases, The Rockefeller University, 1230 York Avenue, New York, NY I002I, USA, Tel: + I 212327 8490, Fax: + I 212327 8574, E-mail: kreek@rockefeller.edu

Received 17 October 2005; revised 9 February 2006; accepted 16 March 2006

Online publication: 22 May 2006 at http://www.acnp.org/citations/ Npp0522060506 I5/default.pdf
}

vulnerability to develop an addictive disease (for a review, Kreek et al, 2005). Of particular interest are the genes of the endogenous opioid system whose expression and/or protein products are either directly or indirectly affected by each of the substances of abuse. Self-administration of opioids, cocaine, alcohol, and nicotine does not develop or is reduced in mu opioid receptor gene (OPRM1) knockout mice (Becker et al, 2000; Berrendero et al, 2002; Hall et al, 2001; Mathon et al, 2005; Roberts et al, 2000). We have shown that a functional single nucleotide polymorphism in the first exon of OPRM1 accounts for up to $21 \%$ of the attributable risk for developing heroin addiction and $11 \%$ of the risk for developing alcoholism in cohorts from central Sweden (Bart et al, 2004, 2005).

This A118G polymorphism (rs1799971) results in an asparagine to aspartic acid substitution at amino-acid position 40 and leads to increased receptor-binding affinity for the endogenous opioid beta-endorphin and increased potency of ion channel activation following beta-endorphin binding (Bond et al, 1998). Two other studies, one in transiently-expressing COS cells (Befort et al, 2001), the other in stable HEK293 cell lines (Beyer et al, 2004), did not replicate these findings. In our prior study (Bond et al, 1998), the variant and prototype receptors were stablytransfected AV-12 cells, which confer $N$-glycosylation. These cells were chosen because, in the mu opioid receptor, amino-acid position 40 is a putative site of glycosylation. Further, a recent report on human receptors harvested from 
post-mortem brain tissue has found that some of the functional effects seen by Bond et al may be related to a decrease in $\mathrm{mu}$ opioid receptor mRNA expression in subjects with a variant $118 \mathrm{G}$ allele (Zhang et al, 2005). Other studies have also identified reduced receptor expression in transfected cell lines of receptors encoded by the $118 \mathrm{G}$ allele, a finding also noted in our ongoing studies (Beyer et al, 2004; Kroslak et al, 2003). The mu opioid receptor system is also involved, through tonic inhibition, in modulation of the stress responsive HPA axis and normal volunteers with a $118 \mathrm{G}$ allele have an increased HPA response (measured through levels of plasma cortisol) following antagonism of this inhibition with the opioid antagonist medication naloxone (Chong et al, 2006; Hernandez-Avila et al, 2003; Wand et al, 2002).

In this report, we tested the hypothesis that, while a $118 \mathrm{G}$ allele influences HPA responsivity to stress and pharmacological probes, it will not affect basal HPA activity measured as plasma levels of ACTH and cortisol.

\section{PATIENTS AND METHODS}

\section{Subjects}

In all, 59 healthy subjects ( 28 female) with no history of substance abuse or dependence (including nicotine) were recruited by newspaper advertisement and by word of mouth. All subjects provided written informed consent for participation in ongoing neuroendocrine studies as well as separate written consent for genetics research. The Rockefeller University Institutional Review Board approved the study protocols and consent forms.

Evaluation for medical and psychiatric inclusion and exclusion criteria were made by an internist or psychiatrist using clinical interview, physical exam, and review of laboratory and corroborative data. Subjects gave informed consent for HIV testing. Aliquots of urine were tested daily, both during the screening process and during the inpatient stay, for the presence of opioids, cocaine, cannabinoids, or benzodiazepines. Subjects included in the study were free of significant medical problems, HIV antibody negative, urine toxicology negative, were not pregnant (urine beta-hCG confirmation upon admission), and did not meet DSM-IV criteria for any axis I diagnosis including substance and/or alcohol abuse or dependence. Female subjects were not on hormone replacement therapy or using hormonal contraceptives. Subjects were not taking prescription medications, and were not regularly using over-the-counter medications or herbal preparations.

\section{Procedure}

Subjects were admitted to the stress-minimized inpatient unit at least one evening prior to the test date. Subjects participated in one of six related neuroendocrine protocols with similar methodology, however, for this report, placeboday data were compiled from all six studies to achieve a large sample size. Subjects fasted at least $9 \mathrm{~h}$ prior to the beginning of testing (between 0930 and $1030 \mathrm{~h}$ ) and were allowed to eat only after the first $2 \mathrm{~h}$ of testing had elapsed. Normal saline placebo $(10 \mathrm{ml})$ was administered through, and blood was withdrawn from, an indwelling intravenous catheter (BD Angiocath Autoguard, Becton, Dickinson, Franklin Lakes, NJ), inserted at least an hour prior to the beginning of testing.

Plasma adrenocorticotropic hormone (ACTH) and cortisol levels were determined in blood samples drawn at sequential time points. Time points started $10 \mathrm{~min}$ prior to, immediately prior to, and then $10,20,30,40,50,60,75$, and $90 \mathrm{~min}$ following placebo administration. Blood was drawn into sodium EDTA vacutainers, and immediately placed on ice. Samples were stored on ice for up to $40 \mathrm{~min}$, and then centrifuged at $4^{\circ} \mathrm{C}$ at $3000 \times g$ for $5 \mathrm{~min}$. Plasma was removed, aliquoted and stored at $-40^{\circ} \mathrm{C}$ until assayed. Plasma ACTH and cortisol levels were determined in duplicate by radioimmunoassay procedures, with slight modifications (ACTH: Nichols Institute, San Juan Capistrano, CA; cortisol: Diagnostic Products, Los Angeles, CA). ACTH intra- and inter-assay coefficients of variation were 9.4 and $15.1 \%$, respectively. Cortisol intraand inter-assay coefficients of variation were 2.5 and $6.0 \%$, respectively.

\section{Genotyping}

Genomic DNA was isolated from peripheral blood lymphocytes. Approximately $100 \mathrm{ng}$ of genomic DNA was amplified by polymerase chain reaction (PCR) using primers designed to amplify the entire coding region of exon 1 of OPRM1. PCR products were electrophoresed on agarose gel to verify amplification size and were then purified and sequenced at The Rockefeller University. The amplification and sequencing primers have been described previously (Bart et al, 2004) and we have compared the accuracy of these primers with a TaqMan-based methodology and found the concordance of genotyping results between the two methods to be greater than 99\% (Proudnikov et al, 2004). Electropherograms were analyzed by two independent readers who were blind to the neuroendocrine data.

\section{Statistical Analysis}

Area under the curve (AUC) from 0 to $90 \mathrm{~min}$ after placebo administration was calculated for each hormone (ACTH and cortisol) in each subject. A two-way analysis of variance (ANOVA), Condition by Genotype was used to evaluate the differences between each hormone and any possible effect of genotype. As there were only two subjects homozygous for the $118 \mathrm{G}$ allele, they were combined in the analyses with the $118 \mathrm{G}$ heterozygotes.

\section{RESULTS}

Subject demographics by A118G allele group are shown in Table 1. Gender distribution was similar for both groups. In accordance with previously documented differences in $118 \mathrm{G}$ allele frequency among ethnicities, there were more African Americans in the prototype group. However, there were more Hispanics in the $118 \mathrm{G}$ allele group than expected. Basal levels of ACTH and cortisol did not differ between genders $(\mathrm{F}(1,55)=1.82, p=0.1832$ and $\mathrm{F}(1,55)=1.18$, $p=0.2815$, respectively) (Figure 1 ). Area under the curve for ACTH did not differ significantly between subjects with a $118 \mathrm{G}$ allele and those without a $118 \mathrm{G}$ allele $(\mathrm{F}(1,55)=3.19$, 
$p=0.0794$ ) (Figure 2a). However, subjects with a $118 \mathrm{G}$ allele had significantly greater cortisol AUC than subjects without a $118 \mathrm{G}$ allele $(\mathrm{F}(1,55)=4.27, p<0.05)$ (Figure $2 \mathrm{~b}$ ). While there was no significant interaction between gender and genotype for either ACTH or cortisol $(\mathrm{F}(1,55)<1.0$ and $\mathrm{F}(1,55)=2.84, p=0.0974$, respectively), a planned comparison of females with a $118 \mathrm{G}$ allele and those with the prototype gene showed significantly greater cortisol AUC in females with a $118 \mathrm{G}$ allele $(p<0.02)$ (Figure $2 \mathrm{c}$ ).

\section{DISCUSSION}

In this report, we found a significant increase in basal levels of plasma cortisol in healthy subjects with a $118 \mathrm{G}$ allele in exon 1 of OPRM1. Previous reports have shown that subjects with a $118 \mathrm{G}$ allele have increased cortisol response following administration of the opioid antagonist naloxone (Hernandez-Avila et al, 2003; Wand et al, 2002; Chong et al, 2006) and, possibly, decreased response to a social stressor (Chong et al, 2006). These reports did not note an effect of the $118 \mathrm{G}$ allele on basal levels of either ACTH or cortisol. Interestingly, neither our study nor the other reports have noted an effect of the $118 \mathrm{G}$ allele on basal or stimulated levels of ACTH. While opioid peptide mRNA has been

Table I Demographic Characteristics

\begin{tabular}{lcc}
\hline Characteristic & Al I 8A $(\mathbf{n = 4 0 )}$ & $\begin{array}{c}\text { Al I 8G }(\mathbf{n}=\mathbf{I 9}) \\
\text { I or } \mathbf{2} \text { copies }\end{array}$ \\
\hline Male $(n)$ & 20 & 11 \\
Race/ethnicity (n) & & \\
White, non-Hispanic & 20 & 9 \\
African American & 17 & 3 \\
White, Hispanic & 2 & 7 \\
Other & 1 & 0 \\
Mean age in years (SD) & $34.1(10.7)$ & $29.1(4.5)$ \\
Mean body mass index (SD) & $25.3(4.5)$ & $27.1(7.0)$ \\
\hline
\end{tabular}

Values represent absolute numbers or means. Group differences in ethnic distribution were evaluated with a $\chi^{2}$ analysis. There was a significant difference $\left(\chi^{2}=10.9 ; \mathrm{df}=2 ; p<0.0 \mathrm{I}\right)$ in the proportion of ethnicities between the prototype group and the group with a II8G allele. detected in the adrenal medulla, there is no known adrenal cortical expression of the mu opioid receptor and, therefore, it is unkown whether the effect of the $118 \mathrm{G}$ variant allele on cortisol in these studies is centrally or peripherally mediated.

A possible effect of gender must also be considered. Wand et al studied only men and Hernandez-Avila et al included only four women (three A118A and one 118G). While Chong et al studied a large cohort including at least 30 women (21 A118A and nine A118G), no basal difference in ACTH or cortisol was noted, although their baseline was determined using only two time points separated by fifteen minutes. Given positron-emission tomography (PET) imaging data indicating that mu opioid receptor-binding potential is higher in women (Zubieta et al, 1999), replication of our findings will be needed with a larger sample size and frequent sample measurements in order to determine if a gene-gender interaction contributes to the increase in basal levels of cortisol noted in $118 \mathrm{G}$ subjects. Also, given the difference in ethnic distribution between groups, the possibility of other, more ethnicity-specific polymorphisms that influence HPA axis function cannot be ruled out. The direct influence of ethnicity on basal and stress-induced cortisol levels has been studied with conflicting results, which indicates that ethnicity alone may not influence cortisol; however, disparities in socioeconomic factors, which are often along ethnic lines may explain these conflicting results (eg Bennett et al, 2004; Masi et al, 2004). This study was not large enough to control for demographic factors such as socioeconomic status and education.

In summary, this preliminary report shows that basal levels of serum cortisol are significantly greater in subjects with a $118 \mathrm{G}$ allele than in subjects with the prototypical A118A genotype. Further work is needed to address whether the differences in basal and stress-induced cortisol response in subjects with a $118 \mathrm{G}$ allele are due to altered receptor function and/or expression, and if these differences contribute to the vulnerability to develop specific addictions and other psychiatric disorders characterized by altered HPA axis responsivity. Whether the effectiveness of treatment agents for these disorders (such as increased treatment response to naltrexone in alcoholics with a $118 \mathrm{G}$ allele described by Oslin et al, 2003) may be influenced by the effects of a $118 \mathrm{G}$ allele on HPA axis responsiveness should also be investigated.
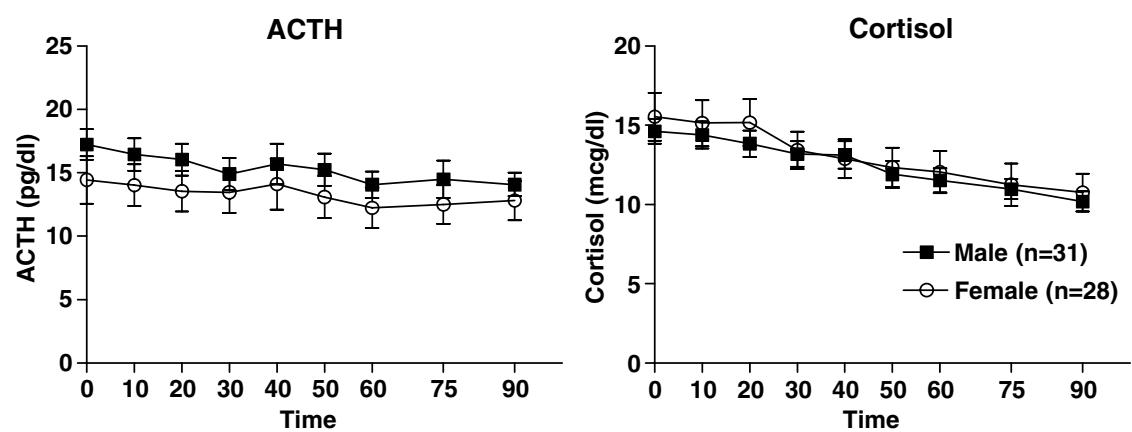

Figure I Plasma levels of adrenocorticotropic hormone and cortisol by gender. Plasma levels from just before to 90 min after injection of placebo are shown for adrenocorticotropic hormone (ACTH, on the left) and cortisol (right). Means and SE are displayed for men and women. There was no significant difference between genders for each hormone. 

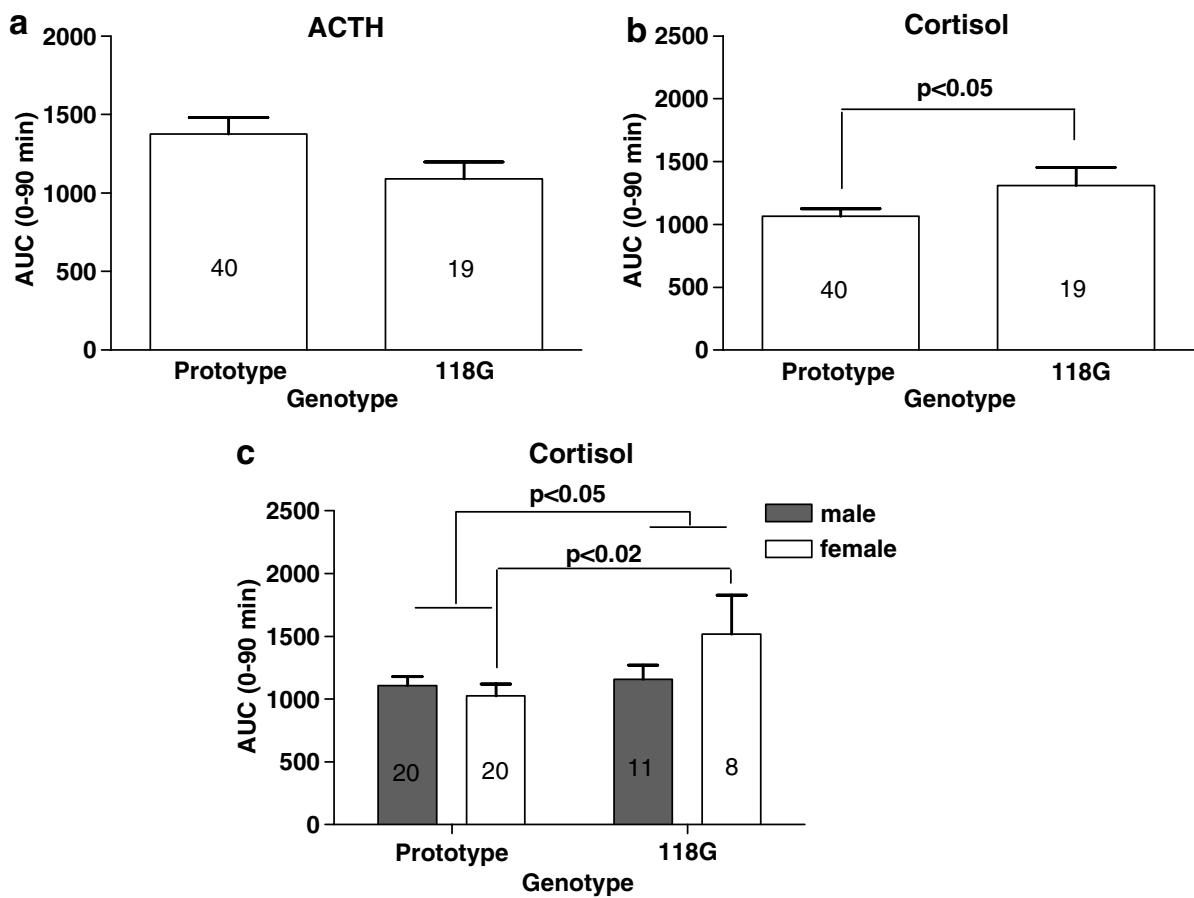

Figure 2 Area under the curve of adrenocorticotropic hormone and cortisol by genotype (prototype vs subjects with a I I 8G allele). (a) The 90-min area under the curve (AUC) for adrenocorticotropic hormone (ACTH) and (b) cortisol are shown for the genetic prototype group and the group with a I I $8 \mathrm{G}$ allele. Analysis of variance showed a significant effect of the I I $8 \mathrm{G}$ allele on cortisol $(p<0.05)$ but not ACTH. (c) AUC for cortisol by genotype and gender is shown, the significant group effect of the II8G allele on cortisol appears to be due to the women with at least one copy of the II8G allele who have significantly greater cortisol levels than women with the prototype gene $(p<0.02)$.

\section{ACKNOWLEDGEMENTS}

This work was supported by National Institutes of Health (NIH) grants DA05130, DA12848 and DA00049. The research was conducted at the Rockefeller University Hospital General Clinical Research Center (NIH/National Center for Research Resources M01RR00102). The authors have no involvement, financial or otherwise, that might potentially bias their work. The authors would like to acknowledge Matthew Randesi for expertise in sequencing and reading electropherograms. Also acknowledged are Johannes Adomako-Mensah, Julia Allen, Lauren Bence, Jason Choi, Nicole Dankert, Caitlin Smith, and Matthew Swift for technical assistance.

\section{REFERENCES}

Bart G, Heilig M, LaForge KS, Pollak L, Leal SM, Ott J et al (2004). Substantial attributable risk related to a functional mu-opioid receptor gene polymorphism in association with heroin addiction in central Sweden. Mol Psychiatry 9: 547-549.

Bart G, Kreek MJ, Ott J, LaForge KS, Proudnikov D, Pollak L et al (2005). Increased attributable risk related to a functional $\mu$ opioid receptor gene polymorphism in association with alcohol dependence in central Sweden. Neuropsychopharmacology 30: 417-422.

Becker A, Grecksch G, Brodemann R, Kraus J, Peters B, Schroeder $\mathrm{H}$ et al (2000). Morphine self-administration in mu-opioid receptor-deficient mice. Naunyn-Schmiedebergs Arch Pharmacol 361: 584-589.

Befort K, Filliol D, Decaillot FM, Gaveriaux-Ruff C, Hoehe MR, Kieffer BL (2001). A single nucleotide polymorphic mutation in the human $\mu$-opioid receptor severely impairs receptor signaling. J Biol Chem 276: 3130-3137.

Bennett GG, Merritt MM, Wolin KY (2004). Ethnicity, education, and the cortisol response to awakening: a preliminary investigation. Ethn Health 9: 337-347.

Berrendero F, Kieffer BL, Maldonado R (2002). Attenuation of nicotine-induced antinociception, rewarding effects, and dependence in $\mu$-opioid receptor knock-out mice. J Neurosci 22: 10935-10940.

Beyer A, Koch T, Schroder H, Schulz S, Hollt V (2004). Effect of the A118G polymorphism on binding affinity, potency and agonistmediated endocytosis, desensitization, and resensitization of the human mu-opioid receptor. J Neurochem 89: 553-560.

Bond C, LaForge KS, Tian M, Melia D, Zhang S, Borg L et al (1998). Single-nucleotide polymorphism in the human mu opioid receptor gene alters beta-endorphin binding and activity: possible implications for opiate addiction. Proc Natl Acad Sci USA 95: 9608-9613.

Chong RY, Oswald L, Yang X, Uhart M, Lin P-I, Swan GS (2006). The mu-opioid receptor polymorphism A118G predicts cortisol responses to naloxone and stress. Neuropsychopharmacology 31: 204-211.

Ehlert U, Gaab J, Heinrichs M (2001). Psychoneuroendocrinological contributions to the etiology of depression, posttraumatic stress disorder, and stress-related bodily disorders: the role of the hypothalamus-pituitary-adrenal axis. Biol Psychiatry 57: 141-152.

Federenko IS, Nagamine M, Hellhammer DH, Wadhwa PD, Wust S (2004). The heretability of hypothalamus pituitary adrenal axis responses to psychosocial stress is context dependent. J Clin Endocrinol Metab 89: 6244-6250.

Hall FS, Sora I, Uhl GR (2001). Ethanol consumption and reward are decreased in $\mu$-opiate receptor knockout mice. Psychopharmacology 154: 43-49. 
Hernandez-Avila CA, Wand G, Luo X, Gelernter J, Kranzler H (2003). Association between the cortisol response to opioid blockade and the Asn40Asp polymorphism at the $\mu$-opioid receptor locus (OPRM1). Am J Med Genet 118B: 60-65.

King AC, Schluger J, Gunduz M, Borg L, Perret G, Ho A et al (1998). Hypothalamic-pituitary-adrenocortical (HPA) axis response and biotransformation of oral naltrexone: preliminary examination of relationship to family history of alcoholism. Neuropsychopharmacology 26: 778-788.

Kreek MJ, Koob GF (1998). Drug dependence: stress and dysregulation of brain reward pathways. Drug Alcohol Depend 51: 23-47.

Kreek MJ, Nielsen DA, Butelman ER, LaForge KS (2005). Genetic influences on impulsivity, risk taking, stress responsivity and vulnerability to drug abuse and addiction. Nature Neurosci 8: 1450-1457.

Kroslak T, Gianotti RG, LaForge KS, Ho A, Kreek MJ (2003). Signaling properties of the human opioid receptor hMOR and the polymorphic variant hMOR(A118G). International Narcotic Research Conference, Perpignan, France, July 6-11, 2003 (abstract).

Linkowski P, van Onderbergen A, Kerkhofs M, Bosson D, Mendlewicz J, van Cauter E (1993). Twin study of the 24-h cortisol profile: evidence for genetic control of the human circadian clock. Am J Physiol 264: E173-E181.

Masi CM, Rickett EM, Hawkley LC, Cacioppo JT (2004). Gender and ethnic differences in urinary stress hormones: the population-based Chicago Health, Aging, and Social Relations study. $J$ Appl Physiol 97: 941-947.

Mathon D, Lesscher H, Gerrits M, Kamal A, Pintar J, Schuller A et al (2005). Increased gabaergic input to ventral tegmental area dopaminergic neurons associated with decreased cocaine reinforcement in mu-opioid receptor knockout mice. $\mathrm{Neu}$ roscience 130: 359-367.

Oslin DW, Berrettini WH, Kranzler H, Pettinati H, Gelernter J, Volpicelli JR et al (2003). A functional polymorphism of the muopioid receptor gene is associated with naltrexone response in alcohol dependent patients. Neuropsychopharmacology 28: 15461552.

Proudnikov D, LaForge KS, Kreek MJ (2004). High-throughout molecular haplotype analysis (allelic assignment) of singlenucleotide polymorphisms by fluorescent polymerase chain reaction. Anal Biochem 335: 165-167.

Roberts A, McDonald J, Heyser C, Kieffer BL, Matthes HW, Koob G et al (2000). Mu-opioid receptor knockout mice do not selfadminister alcohol. J Pharmacol Exp Ther 293: 1002-1008.

Schuckit MA, Gold E, Risch C (1987). Plasma cortisol levels following ethanol in sons of alcoholics and controls. Arch Gen Psychiatry 44: 942-945.

Wand GS, Mangold D, El Deiry S, McCaul ME, Hoover D (1998). Family history of alcoholism and hypothalamic opioidergic activity. Arch Gen Psychiatry 55: 1114-1119.

Wand GS, McCaul M, Yang X, Reynolds J, Gotjen D, Lee S et al (2002). The mu-opioid receptor gene polymorphism (A118G) alters HPA axis activation induced by opioid receptor blockade. Neuropsychopharmacology 26: 106-114.

Zhang Y, Wang D, Johnson AD, Papp AC, Sadee W (2005). Allelic expression imbalance of human mu opioid receptor (OPRM1) caused by variant A118G. J Biol Chem 280: 32618-32624.

Zubieta JK, Dannals R, Frost JJ (1999). Gender and age influences on human brain mu-opioid receptor binding measured by PET. Am J Psychiatry 156: 842-848. 